Article

\title{
Mixed Culture Fermentation and Media Optimization by Response Surface Model: Streptomyces and Brachybacterium Species in Bioflocculant Production
}

\author{
Uchechukwu U. Nwodo * and Anthony I. Okoh \\ Applied and Environmental Microbiology Research Group (AEMREG), Department of Biochemistry \\ and Microbiology, University of Fort Hare, Private Bag X1314, Alice 5700, South Africa; \\ E-Mail: AOkoh@ufh.ac.za
}

* Author to whom correspondence should be addressed; E-Mail: UNwodo@ufh.ac.za;

Tel.: +27-786-273-279; Fax: +27-862-707-453.

Received: 9 May 2014; in revised version: 14 July 2014 / Accepted: 21 July 2014 /

Published: 29 July 2014

\begin{abstract}
The biofloculant production potential of a consortium of Streptomyces and Brachybacterium species were evaluated. Optimum bioflocculant yields (g/L) and flocculation activities (\%) were observed for the following preferred nutritional sources: glucose $(56 \% ; 2.78 \pm 0.15 \mathrm{~g} / \mathrm{L}),\left(\mathrm{NH}_{4}\right)_{2} \mathrm{NO}_{3}(53 \% ; 2.81 \pm 0.37 \mathrm{~g} / \mathrm{L})$ and $\mathrm{CaSO}_{4} \cdot \mathrm{H}_{2} \mathrm{O}(47 \%$; $2.19 \pm 0.13 \mathrm{~g} / \mathrm{L})$. A Plackett-Burman design revealed the critical fermentation media components. The concentrations of these components were optimized [glucose; 16.0, $\left(\mathrm{NH}_{4}\right)_{2} \mathrm{NO}_{3} ; 0.5$ and $\left.\mathrm{CaSO}_{4} \cdot \mathrm{H}_{2} \mathrm{O} ; 1.2(\mathrm{~g} / \mathrm{L})\right]$ through a central composite design with optimum bioflocculant yield of $3.02 \mathrm{~g} / \mathrm{L}$ and flocculation activity of $63.7 \%$. The regression coefficient $\left(\mathrm{R}^{2}=0.6569\right)$ indicates a weak estimation of the model's adequacy and a high lack-of-fit value (34.1\%). Lack of synergy in the consortium may have been responsible for the model inadequacy observed. FTIR spectrometry showed the bioflocculant to be a heteropolysaccharide, while SEM imaging revealed an amorphous loosely arranged fluffy structure with interstial spacing of less than $1 \mu \mathrm{m}$.
\end{abstract}

Keywords: bioflocculant; Brachybacterium; mixed culture; optimization; Streptomyces 


\section{Introduction}

Biopolymeric materials, of extracellular or intracellular origin, synthesized by some species of bacteria, fungi and algae have been variously documented to mediate flocculation of suspended particles in liquid media [1-4]. These biopolymeric substances are referred to as bioflocculants. The growing interest in these biopolymers can be attributed to the advantages they possess over the conventionally used flocculants which include aluminum salts (aluminum sulphate and polyaluminum chloride), derivatives of polyacrylamide and polyethylene imines [5]. These advantages includes being innocuous and biodegradable, and thus environmentally friendly [6].

Neurodegenerative diseases such as Alzheimer's have been associated with polyaluminum chlorides [7], while the derivatives of polyacrylamide and polyethylene imines have similarly been implicated in neurotoxicity and cancer [8-10]. These adverse health effects have been, among other factors, the major motivation for the search for alternative flocculants. Consequent to the aforementioned demerits, some countries in the developed economies have initiated restrictive measures aimed at curbing the application of these conventionally used flocculants in water processing [11].

Appreciable flocculation activities has been reported for bioflocculants produced by several prokaryotes, fungi and a few algae [12-14] however, the high cost of bioflocculant production and low yield has been a major limiting factor to the industrial applications of these biopolymers [15-17]. Hence, the continuing search for microbial species with capabilities for enhanced bioflocculant yield with high flocculation activities [18].

Besides bio-prospecting for novel bioflocculant-producing bacteria, strategies employed for yield optimization of microbial products include mutational analysis and manipulation of nutritional and fermentation conditions [19]. Mixed culture fermentation and the use of industrial wastes as nutritional sources are amongst other production cost reduction strategies. Furthermore, application of mathematical models including factorial and surface response (SRD) designs has proven to be advantageous towards cost minimization and yield optimization. An additional merit of identifying the contributions of the respective input variables and optimizing the proportions of identified critical input variables has been a major reason for the application of these designs [20-23].

In our previous studies, axenic cultures of Brachybacterium sp. UFH and Streptomyces sp. Gansen produced bioflocculants characterized as composed of uronic acids, polysaccharide, and proteins, among other components. The bioflocculants produced by the respective actinobacteria were stable to $\mathrm{pH}$ extremes and high temperature. Besides the optimization of yield through manipulation of fermentation conditions for the axenic cultures, further optimization process was attempted through evaluation of Brachybacterium sp. and Streptomyces sp. as a mixed culture. The critical fermentation media components were determined with the Plackett-Burman (PB) experimental model, while a central composite design (CCD) was used to optimize the identified critical media components. Application of PB and CCD was necessitated by the dearth of information on media optimization for mixed culture fermentation. The bioflocculant produced was purified and characterized. 


\section{Results and Discussion}

\subsection{The Effects of Nutritional Sources on Bioflocculant Production}

The different carbon, nitrogen and cation sources evaluated for optimal utilization for bioflocculant production showed Streptomyces sp. and Brachybacterium sp. consortium to optimally utilize glucose, $\left(\mathrm{NH}_{4}\right)_{2} \mathrm{NO}_{3}$ and $\mathrm{CaSO}_{4} \cdot \mathrm{H}_{2} \mathrm{O}$ respectively (Table 1). The flocculation activities (in percentages) and bioflocculant yields (g/L) achieved by these carbon sources were: $56 \%$ and $2.78 \pm 0.15 \mathrm{~g} / \mathrm{L}$ (glucose), $51 \%$ and $2.52 \pm 0.44 \mathrm{~g} / \mathrm{L}$ (sucrose), $48 \%$ and $2.27 \pm 0.18 \mathrm{~g} / \mathrm{L}$ (fructose). Similarly, the nitrogen sources showed flocculation activities and bioflocculant yields of: $53 \%$ and $2.81 \pm 0.37 \mathrm{~g} / \mathrm{L}\left[\left(\mathrm{NH}_{4}\right)_{2} \mathrm{NO}_{3}\right], 49 \%$ and $1.96 \pm 0.21 \mathrm{~g} / \mathrm{L}$ (urea), $38 \%$ and $1.99 \pm 0.56 \mathrm{~g} / \mathrm{L}$ respectively (Table 1 ). The cation sources with flocculation activities above $40 \%$ were $\mathrm{CaSO}_{4} \cdot \mathrm{H}_{2} \mathrm{O}$ and $\mathrm{MgCl}_{2}$ (Table 1). Although glucose, $\left[\left(\mathrm{NH}_{4}\right)_{2} \mathrm{NO}_{3}\right]$ and $\mathrm{CaSO}_{4} \cdot \mathrm{H}_{2} \mathrm{O}$ were the preferred nutritional sources as they respectively yielded the optimal flocculation activity, the difference in flocculation activities achieved with other nutritional components, were not statistically significant $(p \leq 0.05)$.

Table 1. Nutritional sources optimally utilized by mixed culture of Brachybacterium sp. and Streptomyces sp. for the production of bioflocculant.

\begin{tabular}{cccccccc}
\hline Carbon Source & Glucose & Lactose & Fructose & Sucrose & Maltose & Starch & \\
\hline MFA (\%) & 56 & 42 & 48 & 51 & 33 & 46 & \\
BY (g/L) & $2.78 \pm 0.15$ & $2.34 \pm 0.66$ & $2.27 \pm 0.18$ & $2.52 \pm 0.44$ & $2.09 \pm 0.61$ & $1.99 \pm 0.41$ & \\
Nitrogen source & $\mathrm{Urea}$ & $\left(\mathrm{NH}_{4}\right)_{2} \mathrm{SO}_{4}$ & $\left(\mathrm{NH}_{4}\right)_{2} \mathrm{NO}_{3}$ & $\left(\mathrm{NH}_{4}\right)_{2} \mathrm{Cl}_{4}$ & Peptone & & \\
MFA (\%) & 49 & 36 & 53 & 38 & 42 & & \\
BY (g/L) & $1.96 \pm 0.21$ & $2.03 \pm 0.26$ & $2.81 \pm 0.37$ & $1.99 \pm 0.56$ & $2.31 \pm 0.22$ & & \\
Cation source & $\mathrm{KCl}$ & $\mathrm{NaCl}$ & $\mathrm{MgCl}_{2}$ & $\mathrm{CaSO}_{4} \cdot \mathrm{H}_{2} \mathrm{O}$ & $\mathrm{MnCl} \cdot 4 \mathrm{H}_{2} \mathrm{O}$ & $\mathrm{FeSO}_{4}$ & $\mathrm{FeCl}_{3}$ \\
MFA (\%) & 31 & 29 & 41 & 47 & 32 & 29 & 37 \\
BY (g/L) & $1.58 \pm 0.11$ & $1.26 \pm 0.18$ & $1.89 \pm 0.21$ & $2.19 \pm 0.13$ & $1.74 \pm 0.17$ & $1.55 \pm 0.29$ & $1.82 \pm 0.41$ \\
\hline
\end{tabular}

$\mathrm{MFA}=$ maximum flocculation activity; $\mathrm{BY}=$ Bioflocculant yield.

Nonetheless, the consortium produced bioflocculant in an amount lower than the respective axenic cultures as noted by the yields and flocculation activity. A similar trend was observed with the assessed nitrogen and cation sources. Hence, yield optimization through mixed culture fermentation is achieved only when the respective culture acts in synergy [24]. However, Brachybacterium sp. UFH and Streptomyces sp. Gansen seems to have acted in an antagonistic manner thus leading to the decline of bioflocculant yield and flocculation activity, respectively. The actinobacterial species responsible for the antagonistic effect is not known however, the decreased bioflocculant yield was taken as an indication of antagonism.

The utilization of various nutrient sources for the production of microbial secondary metabolites have been reported for axenic cultures [3,15,25,26], including the production of bioflocculants $[16,17,19]$. However a dearth of information exists with respect to the use of mixed cultures in bioflocculant production, although mixed cultures effective in the degradation of environmental pollutants have been reported [27], among other applications. 


\subsection{Critical Media Components for Bioflocculant Production}

The respective nutritional sources constituting the fermentation media: glucose, $\left(\mathrm{NH}_{4}\right)_{2} \mathrm{NO}_{3}$, $\mathrm{CaSO}_{4} \cdot \mathrm{H}_{2} \mathrm{O}, \mathrm{K}_{2} \mathrm{HPO}_{4}$ and $\mathrm{KH}_{2} \mathrm{PO}_{4}$ were evaluated for their respective contributions towards bioflocculant production with an experimental outlay (Table 2) in accordance with Plackett-Burman design matrix. The observed flocculation activities (measured from experimental trials) and predicted (generated through regression analysis) are in close accord ( $p \geq 0.05$ ). Flocculation activities of 57\% and 56\% were recorded at experimental trials No. 4, 6 and 11 as the optimum (Table 2). The concentrations of media components for these experimental trials were $(\mathrm{g} / \mathrm{L}) ; 12.5$ (glucose), $\left.1\left[\mathrm{NH}_{4}\right)_{2} \mathrm{NO}_{3}\right], 0.5\left(\mathrm{CaSO}_{4} \cdot \mathrm{H}_{2} \mathrm{O}\right), 5.0\left(\mathrm{~K}_{2} \mathrm{HPO}_{4}\right)$ and $2\left(\mathrm{KH}_{2} \mathrm{PO}_{4}\right)$ for trail No. 4, 12.5 (glucose), $\left.1\left[\mathrm{NH}_{4}\right)_{2} \mathrm{NO}_{3}\right], 0.3\left(\mathrm{CaSO}_{4} \cdot \mathrm{H}_{2} \mathrm{O}\right), 5.0\left(\mathrm{~K}_{2} \mathrm{HPO}_{4}\right)$ and $2.5\left(\mathrm{KH}_{2} \mathrm{PO}_{4}\right)$ for trials No. 6 and 10 (glucose), and $\left.1\left[\mathrm{NH}_{4}\right)_{2} \mathrm{NO}_{3}\right], 1\left(\mathrm{CaSO}_{4} \cdot \mathrm{H}_{2} \mathrm{O}\right), 5.0\left(\mathrm{~K}_{2} \mathrm{HPO}_{4}\right)$ and $2\left(\mathrm{KH}_{2} \mathrm{PO}_{4}\right)$ for trial No. 11, respectively. In addition, the regression analysis indicates that glucose, $\left(\mathrm{NH}_{4}\right)_{2} \mathrm{NO}_{3}$ and $\mathrm{CaSO}_{4} \cdot \mathrm{H}_{2} \mathrm{O}$ had positive effects on bioflocculant production, unlike $\mathrm{K}_{2} \mathrm{HPO}_{4}$ and $\mathrm{KH}_{2} \mathrm{PO}_{4}$ (Table 3). However, the regression coefficients $\left(\mathrm{R}^{2}\right) ; 0.5$ (glucose), $0.4\left[\left(\mathrm{NH}_{4}\right)_{2} \mathrm{NO}_{3}\right]$ and $0.1\left(\mathrm{CaSO}_{4} \cdot \mathrm{H}_{2} \mathrm{O}\right)$ shown by the respective nutritional sources indicated very weak impact on the production of bioflocculant by the consortium (Table 3).

Table 2. The matrix of PB design for the determination of critical media components involved in bioflocculant production by Brachybacterium sp. and Streptomyces sp. Consortium.

\begin{tabular}{c|ccccccc}
\hline \multirow{2}{*}{ Runs } & \multicolumn{5}{|c}{ Coded levels/Concentrations $(\mathbf{g} / \mathbf{L})$} & \multicolumn{3}{c}{ Flocculation Activity (\%) } \\
\cline { 2 - 8 } & Glucose & $\left.\mathbf{( N H}_{4}\right)_{2} \mathbf{N O}_{3}$ & $\mathbf{C a S O}_{4} \cdot \mathbf{H}_{2} \mathbf{O}$ & $\mathbf{K}_{2} \mathbf{H P O}_{4}$ & $\mathbf{K H}_{2} \mathbf{P O}_{4}$ & Observed & Predicted \\
\hline 1 & $1(12.5)$ & $1(1.5)$ & $-1(0.3)$ & $1(6.5)$ & $1(2.5)$ & 49 & 51.67 \\
2 & $1(12.5)$ & $-1(1.0)$ & $1(0.5)$ & $1(6.5)$ & $1(2.5)$ & 51 & 51.67 \\
3 & $-1(10.0)$ & $1(1.5)$ & $1(0.5)$ & $1(6.5)$ & $-1(2.0)$ & 53 & 52.0 \\
4 & $1(12.5)$ & $1(1.5)$ & $1(0.5)$ & $-1(5.0)$ & $-1(2.0)$ & 57 & 56.33 \\
5 & $1(12.5)$ & $1(1.5)$ & $-1(0.3)$ & $-1(5.0)$ & $-1(2.0)$ & 52 & 54.33 \\
6 & $1(12.5)$ & $-1(1.0)$ & $-1(0.3)$ & $-1(5.0)$ & $1(2.5)$ & 56 & 52.33 \\
7 & $-1(10.0)$ & $-1(1.0)$ & $-1(0.3)$ & $1(6.5)$ & $-1(2.0)$ & 47 & 48.0 \\
8 & $-1(10.0)$ & $-1(1.0)$ & $1(0.5)$ & $-1(5.0)$ & $1(2.5)$ & 49 & 52.67 \\
9 & $-1(10.0)$ & $1(1.5)$ & $-1(0.3)$ & $1(6.5)$ & $1(2.5)$ & 52 & 50.0 \\
10 & $1(12.5)$ & $-1(1.0)$ & $1(0.5)$ & $1(6.5)$ & $-1(2.0)$ & 53 & 51.67 \\
11 & $-1(10.0)$ & $1(1.5)$ & $1(0.5)$ & $-1(5.0)$ & $1(2.5)$ & 56 & 54.67 \\
12 & $-1(10.0)$ & $-1(1.0)$ & $-1(0.3)$ & $-1(5.0)$ & $-1(2.0)$ & 51 & 50.67 \\
\hline
\end{tabular}

Table 3. Regression analysis indicating critical media components in the production of bioflocculant by Brachybacterium sp. and Streptomyces sp. Consortium.

\begin{tabular}{ccccc}
\hline No. & Media Components & Estimate & $\boldsymbol{t}$-value & $\boldsymbol{p}$-value \\
\hline $\mathrm{x} 1$ & Glucose & 0.519 & 6.107 & 0.9421 \\
$\mathrm{x} 2$ & $\left(\mathrm{NH}_{4}\right)_{2} \mathrm{NO}_{3}$ & 0.421 & 2.426 & 0.8894 \\
$\mathrm{x} 3$ & $\mathrm{CaSO}_{4} \cdot \mathrm{H}_{2} \mathrm{O}$ & 0.119 & 2.561 & 0.1527 \\
$\mathrm{x} 4$ & $\mathrm{~K}_{2} \mathrm{HPO}_{4}$ & -0.327 & -1.336 & 0.3810 \\
x5 & $\mathrm{KH}_{2} \mathrm{PO}_{4}$ & -0.244 & -0.349 & 0.1449 \\
\hline
\end{tabular}


The critical media components identified through the Plackett-Burman design model were glucose, $\left(\mathrm{NH}_{4}\right)_{2} \mathrm{NO}_{3}$ and $\mathrm{CaSO}_{4} \cdot \mathrm{H}_{2} \mathrm{O}$, although their significance with respect to bioflocculant production with the consortium was low, with only glucose barely surpassing $50 \%$ while $\mathrm{CaSO}_{4} \cdot \mathrm{H}_{2} \mathrm{O}$ was estimated to have about an $11 \%$ influence. Dipotassium hydrogen phosphate and potassium dihydrogen phosphate showed a negative input, respectively, on the production of bioflocculant, hence their input may be deemed as insignificant. Nonetheless, besides bioflocculant production these salts may have served in a $\mathrm{pH}$ buffering function thus maintaining the physiological $\mathrm{pH}$ of the culture balanced. The identification of critical media components serves to reduce the cost of fermentation if industrial application is envisaged.

\subsection{RSD Optimization of Critical Media Components for the Production of Bioflocculant}

Glucose, $\left(\mathrm{NH}_{4}\right)_{2} \mathrm{NO}_{3}$ and $\mathrm{CaSO}_{4} \cdot \mathrm{H}_{2} \mathrm{O}$ were next optimized in a 3-factor-5-level central composite design (Table 4) following their emergence as critical media components in the PB design experimentation.

Table 4. Central composite design matrix for critical media components showing the observed and predicted values for flocculation activity and bioflocculant yield.

\begin{tabular}{|c|c|c|c|c|c|c|c|}
\hline \multirow{2}{*}{ Runs } & \multirow{2}{*}{ Glucose } & \multirow{2}{*}{$\left(\mathrm{NH}_{4}\right)_{2} \mathrm{NO}_{3}$} & \multirow{2}{*}{$\mathrm{CaSO}_{4} \cdot \mathrm{H}_{2} \mathrm{O}$} & \multicolumn{2}{|c|}{ Flocculation Activity (\%) } & \multicolumn{2}{|c|}{ Bioflocculant Yield (g/L) } \\
\hline & & & & Observed & Predicted & Observed & Predicted \\
\hline 1 & $12.0(-1)$ & $0.5(-1)$ & $1.2(-1)$ & 52.5 & 53.68 & 2.53 & 2.48 \\
\hline 2 & $12.0(-1)$ & $0.5(-1)$ & $1.6(+1)$ & 49.8 & 53.68 & 2.31 & 2.39 \\
\hline 3 & $12.0(-1)$ & $1.5(+1)$ & $1.2(-1)$ & 58.1 & 56.12 & 2.92 & 2.74 \\
\hline 4 & $12.0(-1)$ & $1.5(+1)$ & $1.6(+1)$ & 60.3 & 56.12 & 2.88 & 2.87 \\
\hline 5 & $16.0(+1)$ & $0.5(-1)$ & $1.2(-1)$ & 63.7 & 55.53 & 3.02 & 2.93 \\
\hline 6 & $16.0(+1)$ & $0.5(-1)$ & $1.6(+1)$ & 49.2 & 55.53 & 2.17 & 2.25 \\
\hline 7 & $16.0(+1)$ & $1.5(+1)$ & $1.2(-1)$ & 61.0 & 57.97 & 2.92 & 2.74 \\
\hline 8 & $16.0(+1)$ & $1.5(+1)$ & $1.6(+1)$ & 53.4 & 57.97 & 2.33 & 2.28 \\
\hline 9 & $10.64(-1.73)$ & $1.0(0)$ & $1.4(0)$ & 51.2 & 54.27 & 2.46 & 2.51 \\
\hline 10 & $17.36(+1.73)$ & $1.0(0)$ & $1.4(0)$ & 54.8 & 57.39 & 2.29 & 2.39 \\
\hline 11 & $14.0(0)$ & $0.36(-1.73)$ & $1.4(0)$ & 58.6 & 54.26 & 2.61 & 2.54 \\
\hline 12 & $14.0(0)$ & $1.74(+1.73)$ & $1.4(0)$ & 56.1 & 57.64 & 2.57 & 2.81 \\
\hline 13 & $14.0(0)$ & $1.0(0)$ & $1.06(-1.73)$ & 53.3 & 55.83 & 2.48 & 2.74 \\
\hline 14 & $14.0(0)$ & $1.0(0)$ & $1.84(+1.73)$ & 57.2 & 55.83 & 2.33 & 2.26 \\
\hline 15 & $14.0(0)$ & $1.0(0)$ & $1.4(0)$ & 56.4 & 55.83 & 2.31 & 2.44 \\
\hline 16 & $14.0(0)$ & $1.0(0)$ & $1.4(0)$ & 55.9 & 55.83 & 2.47 & 2.44 \\
\hline 17 & $14.0(0)$ & $1.0(0)$ & $1.4(0)$ & 56.2 & 55.83 & 2.56 & 2.44 \\
\hline 18 & $14.0(0)$ & $1.0(0)$ & $1.4(0)$ & 56.9 & 55.83 & 2.34 & 2.44 \\
\hline 19 & $14.0(0)$ & $1.0(0)$ & $1.4(0)$ & 56.0 & 55.83 & 2.71 & 2.44 \\
\hline 20 & $14.0(0)$ & $1.0(0)$ & $1.4(0)$ & 56.2 & 55.83 & 2.36 & 2.44 \\
\hline
\end{tabular}

The respective proportion of critical media with the highest flocculation activities were $16.0 \mathrm{~g} / \mathrm{L}$, $0.5 \mathrm{~g} / \mathrm{L}$ and $1.6 \mathrm{~g} / \mathrm{L}$ of glucose, $\left(\mathrm{NH}_{4}\right)_{2} \mathrm{NO}_{3}$ and $\mathrm{CaSO}_{4} \cdot \mathrm{H}_{2} \mathrm{O}$, respectively, following the twenty experimental trials shown in the 3-factor-5-level CCD matrix. The flocculation activity and bioflocculant yield achieved at this media components optimum were $63.7 \%$ and $3.02 \mathrm{~g} / \mathrm{L}$, respectively. 
Following analysis of variance, the response surface was fitted to a second order model (Table 5). The relatively high regression coefficient value obtained $\left(\mathrm{R}^{2}=0.6569\right)$, implied a $65.69 \%$ variability with respect to enhancing bioflocculant production as earmarked by the flocculation activity shown by Brachybacterium sp. and Streptomyces sp. consortium.

Table 5. Analysis of variance showing fitted quadratic polynomial model for optimization of flocculation activity by Brachybacterium sp. and Streptomyces sp. consortium fermentation.

\begin{tabular}{ccccccc}
\hline \multirow{2}{*}{ Source } & \multicolumn{6}{c}{ Flocculation Activity } \\
\cline { 2 - 7 } & DF & SS & MS & F-ratio & $\boldsymbol{p}$-value & $\mathbf{R}^{\mathbf{2}}$ \\
\hline Regression model & 9 & 165.1615 & 18.3513 & 2.13 & 0.127576 & 0.656946 \\
Linear & 3 & 44.2462 & 14.7487 & 1.71 & 0.227695 & 0.175994 \\
Quadratic & 3 & 18.5453 & 6.1818 & 0.72 & 0.564227 & 0.073766 \\
Lin x Lin & 3 & 102.37 & 34.1233 & 3.96 & 0.042518 & 0.407187 \\
Total Error & 10 & 86.2466 & 8.6247 & & & 0.343054 \\
Lack of Fit & 5 & 85.6132 & 17.1226 & 135.18 & 0.000025 & 0.340535 \\
Pure Error & 5 & 0.63333 & 0.12667 & & & 0.002519 \\
\hline & \multicolumn{7}{c}{ Bioflocculant Yield } & \\
\cline { 2 - 7 } Source & DF & SS & MS & F-ratio & $\boldsymbol{p}$-value & $\mathbf{R}^{\mathbf{2}}$ \\
\hline Regression model & 9 & 0.7881873 & 875.7637 & 2.43 & 0.091091 & 0.686541 \\
Linear & 3 & 0.3663863 & 0.1221288 & 3.39 & 0.061856 & 0.319137 \\
Quadratic & 3 & 0.122301 & 0.040767 & 1.13 & 0.382087 & 0.106529 \\
Lin x Lin & 3 & 0.2995 & 998.3333 & 2.77 & 0.096567 & 0.260876 \\
Total Error & 10 & 0.3598677 & 359.8677 & & & 0.313459 \\
Lack of Fit & 5 & 0.2403843 & 480.7687 & 2.01 & 0.230646 & 0.209384 \\
Pure Error & 5 & 0.1194833 & 238.9667 & & & 0.104075 \\
\hline
\end{tabular}

$\mathrm{DF}=$ degree of freedom; $\mathrm{SS}=$ Sum of square; $\mathrm{MS}=$ Mean square.

On the same note, the F-test obtained from the regression analysis validates the result with probability value of 0.1276 and the coefficient for the lack-of-fit value $\left(\mathrm{R}^{2}=0.341\right)$ which was not statistically significant $(p \leq 0.000025)$. Hence, there is an indication of the model adequacy for the prediction of enhanced flocculation activity following the assay conditions (Table 5).

Similarly, the analysis of variance for the bioflocculant yield (Table 5) shows a regression coefficient of $\mathrm{R}^{2}=0.6865$ thus, an indication of $68.65 \%$ adequacy. The adequacy of this model has been shown in the harvesting of high-density cultures of Scenedesmus sp. through flocculation [28], activity optimization for composite bioflocculant and polyaluminum chloride [29] and in bioflocculant production optimization by the axenic culture of Halomonas sp.V3a' [15].

The levels of significance of the main effects of glucose, $\left(\mathrm{NH}_{4}\right)_{2} \mathrm{NO}_{3}$ and $\mathrm{CaSO}_{4} \cdot \mathrm{H}_{2} \mathrm{O}$ to the production of bioflocculant were $1.8 \%, 91.3 \%$ and $28.9 \%$ respectively, as indicated by the linear model (Table 6). However, following the quadratic model $\left(\mathrm{NH}_{4}\right)_{2} \mathrm{NO}_{3}$ and $\mathrm{CaSO}_{4} \cdot \mathrm{H}_{2} \mathrm{O}$ showed positive contribution to bioflocculant yield while glucose did not. The negative regression coefficients shown by glucose following the quadratic polynomial model is an indication of the low impact shown by this carbon source towards enhancing bioflocculant yield during fermentation by the consortium. The interaction between glucose, $\left(\mathrm{NH}_{4}\right)_{2} \mathrm{NO}_{3}$ and $\mathrm{CaSO}_{4} \cdot \mathrm{H}_{2} \mathrm{O}$ showed that $\left(\mathrm{NH}_{4}\right)_{2} \mathrm{NO}_{3}$ and $\mathrm{CaSO}_{4} \cdot \mathrm{H}_{2} \mathrm{O}$ was significant while the rest was not, as their coefficients of estimate were negative (Table 6). 
Table 6. Second order polynomial model following regression analysis of flocculation activity optimization for Brachybacterium sp. and Streptomyces sp. consortium.

\begin{tabular}{|c|c|c|c|c|}
\hline Parameter & Estimate & Standard Error & t-Value & $p$-Value \\
\hline Intercept & -121.1504 & & & \\
\hline Glucose & 18.66811 & 6.626398 & 2.82 & 0.018247 \\
\hline$\left(\mathrm{NH}_{4}\right)_{2} \mathrm{NO}_{3}$ & 2.500087 & 22.24044 & 0.11 & 0.912721 \\
\hline $\mathrm{CaSO}_{4} \cdot \mathrm{H}_{2} \mathrm{O}$ & 63.57429 & 56.72536 & 1.12 & 0.288592 \\
\hline Glucose $\times$ Glucose & -0.2474871 & 0.1938682 & -1.28 & 0.230601 \\
\hline$\left(\mathrm{NH}_{4}\right)_{2} \mathrm{NO}_{3} \times\left(\mathrm{NH}_{4}\right)_{2} \mathrm{NO}_{3}$ & 2.360935 & 4.069187 & 0.58 & 0.574621 \\
\hline $\mathrm{CaSO}_{4} \cdot \mathrm{H}_{2} \mathrm{O} \times \mathrm{CaSO}_{4} \cdot \mathrm{H}_{2} \mathrm{O}$ & 3.926695 & 14.69922 & 0.27 & 0.794792 \\
\hline Glucose $\times\left(\mathrm{NH}_{4}\right)_{2} \mathrm{NO}_{3}$ & -1.825 & 1.038307 & -1.76 & 0.109316 \\
\hline Glucose $\times \mathrm{CaSO}_{4} \cdot \mathrm{H}_{2} \mathrm{O}$ & -6.75 & 2.595768 & -2.60 & 0.026474 \\
\hline$\left(\mathrm{NH}_{4}\right)_{2} \mathrm{NO}_{3} \times \mathrm{CaSO}_{4} \cdot \mathrm{H}_{2} \mathrm{O}$ & 14.75 & 10.38307 & 1.42 & 0.185859 \\
\hline
\end{tabular}

The three dimension surface response plot (Figure 1) showing the concentrations of critical media components with response (flocculation activity) revealed that at a higher concentration of glucose and lower concentration of $\mathrm{CaSO}_{4} \cdot \mathrm{H}_{2} \mathrm{O}$, flocculation activity increased (Figure 1A). Likewise, at higher concentrations of glucose and $\left(\mathrm{NH}_{4}\right)_{2} \mathrm{NO}_{3}$ flocculation activities increased (Figure 1C) while the interaction between glucose and $\left(\mathrm{NH}_{4}\right)_{2} \mathrm{NO}_{3}$ apparently showed no increase in flocculation activity at any level (Figure 1B). Consequently, the optimum ratio of the critical media components for the production of bioflocculant by the consortium of Brachybacterium sp. and Streptomyces sp. were: $16.0 \mathrm{~g} / \mathrm{L}$ (glucose), $0.5 \mathrm{~g} / \mathrm{L}\left[\left(\mathrm{NH}_{4}\right)_{2} \mathrm{NO}_{3}\right]$ and $1.2 \mathrm{~g} / \mathrm{L}\left(\mathrm{CaSO}_{4} \cdot \mathrm{H}_{2} \mathrm{O}\right)$, respectively. The maximum flocculation activity and bioflocculant yield achieved were $63.7 \%$ and $3.02 \mathrm{~g} / \mathrm{L}$, respectively.

Figure 1. Three dimensional representations of interactions of critical media components after flocculation activity optimization following application of surface response design.

A

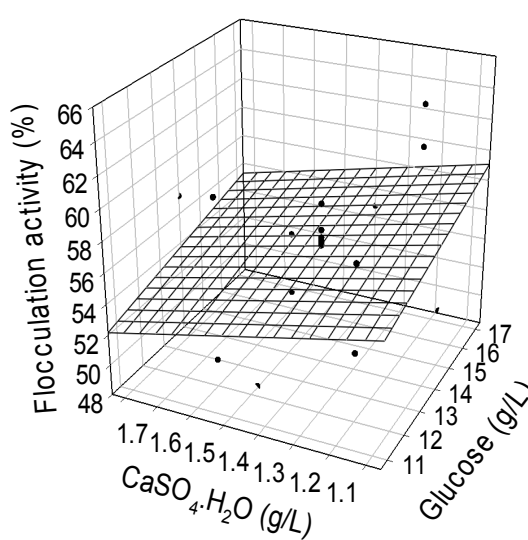

B

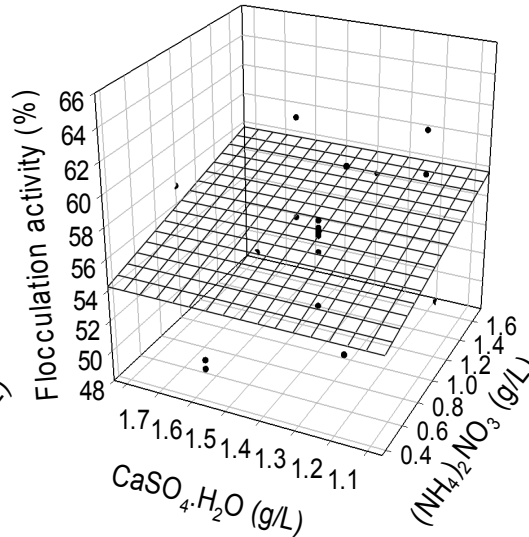

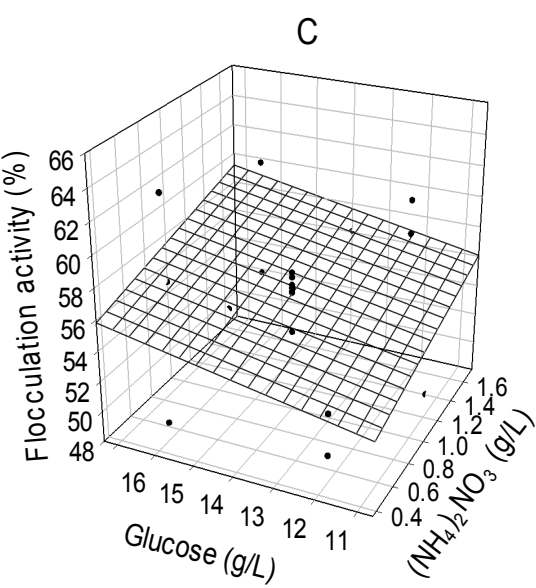

The feasibility of optimizing critical media components is grim if cultures are unable to grow effectively. However, since we did not ascertain the survival of the respective axenic culture in the consortium then, it will be prudent not state that growth was poor particularly as it has been shown that bioflocculant production occurs at the exponential phase of bacterial growth [5,30]. The central composite design revealed the optimum ratio of respective critical media components for bioflocculant 
production while the $\mathrm{PB}$ design showed the utmost contribution towards bioflocculant production to have come from $\left(\mathrm{NH}_{4}\right)_{2} \mathrm{NO}_{3}$ and no clear reason can be adduced to this observation as carbon sources are known to be the most relevant factors for microbial growth. On the other hand, it may be that nitrogen sources were more important in bioflocculant production. Microbial secondary metabolites including poly- $\gamma$-glutamic acid from Bacillus subtilis RKY3 [31], bioflocculants from axenic culture of Halomonas sp. V3a' [15], biosurfactants production by probiotic bacteria [32] and in the production of cold active protease by a psychrophilic bacteria belonging to the genus of Colwellia [33] have been optimized through response models. Despite the fact that surface response methodology is known for adequacy in yield optimization (secondary metabolites) and enhancing the output of desired effects, it did not show adequacy in the mixed culture fermentation as a negative regression coefficient was achieved. This may still be attributed to the antagonistic effects of the biomolecules produced in the fermentation process.

\subsection{Micrographic Imaging and Compositional Characteristics of the Purified Bioflocculant}

Electron micrographic imaging of the purified bioflocculant showed loosely packed fluffy materials with irregular arrangement patterns (Figure 2). The interstices between the crispy flakes were less than $1 \mu \mathrm{m}$ in size. The Fourier transform infrared spectrum (Figure 3) of the purified bioflocculant showed broad stretching peaks at 3589.78 to $3294.42\left(\mathrm{~cm}^{-1}\right)$, characteristic of hydroxyl groups from polymeric, dimeric and monomeric $\mathrm{OH}$ groups. Similarly, peaks from 2958.70 to $2854.39 \mathrm{~cm}^{-1}$ correspond to weak C-H stretching bands from methylene groups, and those from 1654.77 to $1539.01 \mathrm{~cm}^{-1}$ are indicative of the presence of aromatic rings [5,34,35]. Furthermore, wave numbers 1455.10 to $1395.22 \mathrm{~cm}^{-1}$ and 1242.18 to $1047.30 \mathrm{~cm}^{-1}$ shown were typical of phenol and tertiary alcohol $\mathrm{OH}$ bend, indicative of the presence of carboxylic groups, carboxylate ions, aromatic ring stretch and $\mathrm{C}-\mathrm{O}$ and $\mathrm{C}-\mathrm{O}-\mathrm{C}$ from polysaccharides [34].

Figure 2. Scan electron micrographic image of the purified bioflocculant produced by the consortium of Brachybacterium sp. and Streptomyces sp.

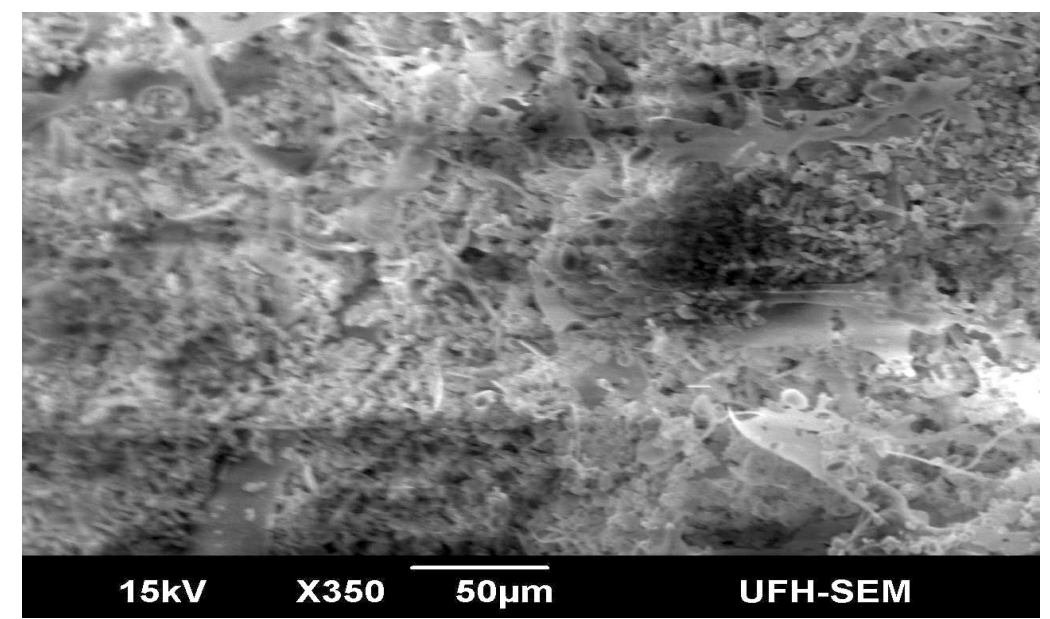


Figure 3. FTIR spectrum of purified bioflocculant from mixed culture fermentation of Brachybacterium sp. UFH and Streptomyces sp. Gansen.

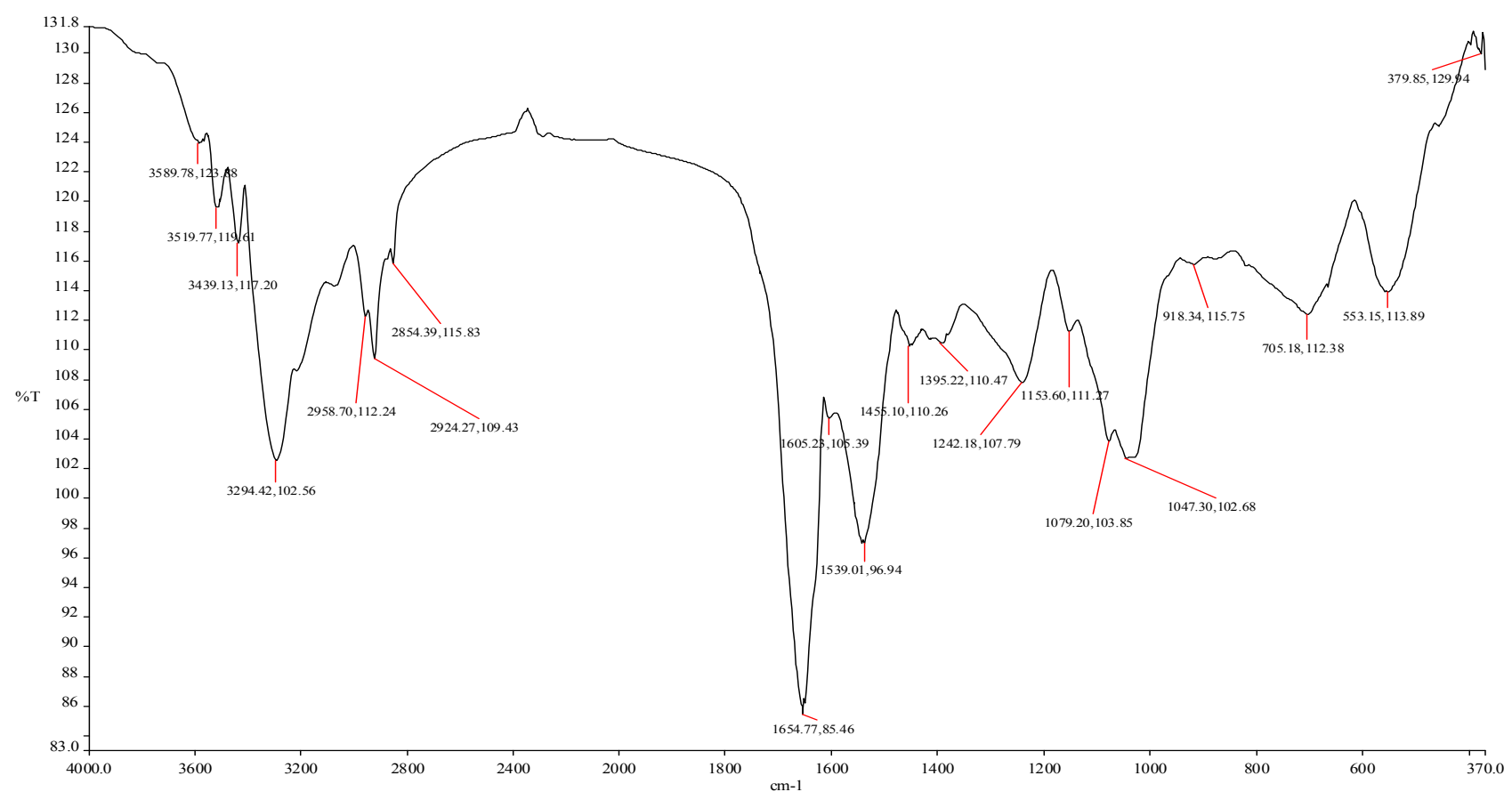

The loose amorphous fluffy nature of the bioflocculant is a marked variation from the clump-like nature shown by bioflocculants with high flocculation activity [5]. Similarly, the micrographic image of the respective axenic cultures was more compact, hence it may be suggested that the formation of bioflocculant was adversely affected in the consortium. The loose nature may also be understood as weak bonding between the molecules constituting the bioflocculant which leads to the low flocculation activity observed. The various functional groups such as hydroxyl, benzylic, allylic, carboxyl, esters and amino groups, amongst others, shown by FTIR spectroscopy are suggestive of an amalgam of polymers containing uronic acids, carbohydrates, glycoproteins and proteins.

\section{Experimental Section}

\subsection{Test Bacterial Strains}

Cultures of Brachybacterium sp. UFH (accession number HQ537131) and Streptomyces sp. Gansen (accession number HQ537129), preserved at $-80{ }^{\circ} \mathrm{C}$ as part of the culture collection of the Applied and Environmental Microbiology Research Group (AEMREG), University of Fort Hare, South Africa were reactivated by inoculating $20 \mu \mathrm{L}$ of the glycerol stock into a sterile $5 \mathrm{~mL}$ sterile broth composed of $3 \mathrm{~g}$ beef extract, $10 \mathrm{~g}$ tryptone and $5 \mathrm{~g} \mathrm{NaCl}$ (per liter), respectively, and incubated overnight at $28^{\circ} \mathrm{C}$.

\subsection{Evaluating Carbon, Nitrogen and Cation Sources for Bioflocculant Production}

The activated actinobacteria species, Brachybacterium sp. UFH and Streptomyces sp. Gansen were adjusted to cell densities of about $1.5 \times 10^{8} \mathrm{cfu} / \mathrm{mL}$ and aliquots of $2 \mathrm{~mL}$ were inoculated into $200 \mathrm{~mL}$ of sterile basal salt media composed of the following $(\mathrm{g} / \mathrm{L})$ : glucose, 10 ; tryptone, $1 ; \mathrm{K}_{2} \mathrm{HPO}_{4}, 5$; $\mathrm{KH}_{2} \mathrm{PO}_{4}, 2$ and $\mathrm{MgSO}_{4} \cdot 7 \mathrm{H}_{2} \mathrm{O}, 0.3$. The fermentation medium was adjusted to $\mathrm{pH} 7$ and incubated at a 
temperature of $30{ }^{\circ} \mathrm{C}$ with an agitation speed of $160 \mathrm{rpm}$ for a period of $72 \mathrm{~h}$. The broth, after the incubation period, was centrifuged at 3,000 rpm for $30 \mathrm{~min}$ at $15^{\circ} \mathrm{C}$ and the cell-free supernatant was assessed for flocculation activity. Fructose, sucrose, lactose, maltose and starch respectively served as sole carbon sources, while the sole nitrogen and cation sources evaluated included urea, ammonium sulphate, ammonium nitrate, ammonium chloride, peptone, monovalent salts ( $\mathrm{KCl}$ and $\mathrm{NaCl})$, divalent salts $\left(\mathrm{MgSO}_{4}, \mathrm{CaSO}_{4} \cdot \mathrm{H}_{2} \mathrm{O}, \mathrm{MnCl} \cdot 4 \mathrm{H}_{2} \mathrm{O}\right.$, and $\left.\mathrm{FeSO}_{4}\right)$ and trivalent salts $\left(\mathrm{FeCl}_{3}\right)$, respectively

\subsection{Determination of Flocculation Activity}

About $0.3 \mathrm{~mL}$ of $1 \% \mathrm{CaCl}_{2}$ and $0.2 \mathrm{~mL}$ of cell free broth (bioflocculant rich broth) were added to $10 \mathrm{~mL}$ of kaolin suspension $(4.0 \mathrm{~g} / \mathrm{L})$ in a test tube. The mixture was vortexed using a vortex mixer (VM-1000, Digisystem, New Taipei City, Taiwan) for $30 \mathrm{~s}$ and kept still for $5 \mathrm{~min}$, after which $2 \mathrm{~mL}$ of the upper layer was carefully withdrawn and its optical density (OD) read spectrophotometrically (Helios Epsilon, Pittsford, NY, USA) at $550 \mathrm{~nm}$ wavelength. Control included repeating same process however, the bioflocculant broth was replaced with sterile (un-inoculated) fermentation medium $[5,19]$. All assays were in triplicates and flocculation activity calculated using the following equations:

$$
\text { Flocculating activity }=\{(\mathrm{A}-\mathrm{B}) / \mathrm{A}\} \times 100 \%
$$

where $\mathrm{A}$ and $\mathrm{B}$ are $\mathrm{OD}_{550}$ (optical density; $550 \mathrm{~nm}$ ) of the control and sample, respectively.

\subsection{Critical Media Components Determination via Plackett-Burman Design}

Critical media components for the production of bioflocculant by the mixed culture were assessed using the Plackett-Burman (PB) design in an " $n$ " variable screening of $n+1$ experiments [15]. The carbon, nitrogen and cation sources yielding optimal flocculation activity were evaluated with other media components. The " $\mathrm{n}$ " variables were glucose, $\mathrm{CaSO}_{4} \cdot \mathrm{H}_{2} \mathrm{O}$ and $\left(\mathrm{NH}_{4}\right)_{2} \mathrm{NO}_{3}, \mathrm{~K}_{2} \mathrm{HPO}_{4}$ and $\mathrm{KH}_{2} \mathrm{PO}_{4}$ which were investigated at two levels (concentrations) of each variable, "high" and "low" were used and was designated as +1 and -1 respectively (Table 2). All experimental trials were carried out in triplicate and the average flocculation activity was used as the response variable. Regression analysis revealed media components with significant $(p<0.05)$ effect on flocculation activity, and these components were evaluated in further optimization experiments. NCSS 2007 (Statistical Analysis and Graphics Software, Kaysville, UT, USA), was used to design and developed the PB experimental design based on the following first-order model:

$$
Y=b o+\sum_{i=1}^{k} b i x i
$$

where $\mathrm{Y}=$ the response (flocculation activity), $\mathrm{bo}=$ model intercept, $\mathrm{bi}=$ linear coefficient, $\mathrm{xi}=$ level (concentrations) of the independent variable, and $\mathrm{k}=$ number of involved variables (media components).

\subsection{Critical Media Components Optimization through the Central Composite Design}

Media components identified by the PB design as critical for bioflocculant production were optimized through the response surface methodology (RSM). A central composite design (CCD) model was generated and critical media components; glucose, $\mathrm{CaSO}_{4} \cdot \mathrm{H}_{2} \mathrm{O}$ and $\left(\mathrm{NH}_{4}\right)_{2} \mathrm{NO}_{3}$ were fitted into the model using the 3-factor-5-level CCD [22]. Experimental runs were all carried out in triplicate 
and the average of both flocculation activity and bioflocculant yield at each run were used as the response variable. The linear relationship between the response variables (flocculation activity and bioflocculant yield, respectively) and the independent variables were respectively fit to the second order polynomial model as shown below:

$$
Y=b o \sum_{i=1}^{k} b i x i+\sum_{i=1}^{k} b i i x^{2}+\sum_{i=1}^{k} \quad \sum_{i=1}^{k} \text { bijxixj, } i \neq j
$$

where $\mathrm{Y}=$ response variable (flocculation activity), bo = coefficient of interception, bi = coefficient of linear effect, bii $=$ coefficient of the quadratic effect, bij $=$ coefficient of interaction effect when $\mathrm{i}<\mathrm{j}$ and $\mathrm{k}$ which are the involved variables (media components).

\subsection{Bioflocculant Purification}

The fermentation broth was centrifuged $\left(3,000 \mathrm{rpm}, 30 \mathrm{~min}, 15^{\circ} \mathrm{C}\right)$ and cell pellets separated from the supernatant by decantation. The supernatant was mixed with ice cold ethanol (95\%), at volume to volume ratio of $1: 4$ and kept at $4{ }^{\circ} \mathrm{C}$ in a cold cabinet for $16 \mathrm{~h}$. The ethanol and cell free broth mixture was centrifuged $\left(10,000 \mathrm{rpm}, 30 \mathrm{~min}, 15^{\circ} \mathrm{C}\right)$ and the residue redissolved in distilled water at a ratio of 1:4 (v/v). The procedure was successively repeated twice and the purified bioflocculant was lyophilized and vacuum dried [1,23]. The lyophilized fraction was used for further studies.

\subsection{SEM Imaging and FTIR Spectroscopy of the Purified Bioflocculant}

Purified bioflocculant was placed on carbon coated stub and gold coated in a gold coating chamber, using Eiko IB.3 ION coater. Scanning electron microscopic (SEM) image of the gold coated bioflocculant was obtained using JEOL JSM-6390LV FEI XL30 (JEOL, Peabody, MA, USA) scan electron microscope. Functional groups present in the bioflocculant were determined using a Fourier transform infrared (FT-IR) spectrophotometer (2000 FTIRS Spectrometer; Perkin Elmer Systems, Waltham, MA, USA) over a wavenumber range of 4000 to $500 \mathrm{~cm}^{-1}$.

\section{Conclusions}

In conclusion, the consortium of Brachybacterium sp. UFH and Streptomyces sp. Gansen produced bioflocculant with low flocculation activity and in low yield when compared to the respective axenic culture. The application of response surface design marginally improved the yield however, the model was not adequate as the antagonistic effect of the culture metabolites impeded effective synthesis of bioflocculant. Although mixed culture is an effective tool in optimization of desired effects, synergy is essential for the desired effects to be achieved.

\section{Acknowledgments}

We express our profound gratitude to the Govan Mbeki Research and Development Center (GMRDC), University of Fort Hare, for funding this research. 


\section{Author Contributions}

NUU; Executed the experiment, extracted the data and drafted the manuscript. OAI; designed and supervised the research as well as proof read the final version of the manuscript.

\section{Conflicts of Interest}

We declare that there are no conflicts of interest.

\section{References}

1. Yokoi, H.; Natsuda, O.; Sachio, J.H.; Takasaki, Y. Characteristics of a biopolymer flocculant produced by Bacillus sp. PY-90. J. Ferment. Bioeng. 1995, 4, 378-380.

2. Jang, J.H.; Ike, M.; Kim, S.M.; Fujita, M. Production of a Novel bioflocculant by fed-batch culture of Citrobacter sp. Biotechnol. Lett. 2001, 23, 593-597.

3. Haijun, W.; Qingbiao, L.; Rui, L.; Yuanpeng, W.; Xiaoling, Z.; Ning, H. Fed-batch production of a bioflocculant from Corynebacterium glutamicum. J. Ind. Microbiol. Biotechnol. 2010, 37, 1203-1209.

4. Luvuyo, N.; Nwodo, U.U.; Mabinya, L.V.; Okoh, A.I. Studies on bioflocculant production by $a$ consortium of two bacterial isolates: Methylobacterium sp. Obi and Actinobacterium sp. Mayor. BMC Biotechnol. 2013, 13, 62 .

5. Nwodo, U.U.; Agunbiade, M.O.; Green, E.; Mabinya, L.V.; Okoh, A.I. A freshwater streptomyces, isolated from Tyume River, produces a predominantly extracellular glycoprotein bioflocculant. Int. J. Mol. Sci. 2012, 13, 8679-8695.

6. Gao, J.; Bao, H.; Xin, M.; Liu, Y.; Li, Q.; Zhang, Y. Characterization of a bioflocculant from a newly isolated Vagococcus sp. W31. J. Zhejiang Univ. Sci. B 2006, 7, 186-192.

7. Banks, W.A.; Niehoff, M.L.; Drago, D.; Zatta, P. Aluminum complexing enhances amyloid protein penetration of blood-brain barrier. Brain Res. 2006, 1116, 215-221.

8. Dearfield, K.L.; Abernathy, C.O.; Ottley, M.S.; Brantner, J.H.; Hayes, P.F. Acrylamide: Its metabolism, developmental and reproductive effects, genotoxicity and carcinogenicity. Mutant Res. 1988, 195, 45-77.

9. Polizzi, S.; Pira, E.; Ferrara, M.; Buginani, M.; Papaleo, A.; Albera, R.; Palmi, S. Neurotoxic effects of aluminum among foundry workers and Alzheimer's disease. Neurotoxicology 2002, 23, 761-774.

10. Rudén, C. Acrylamide and cancer risk-expert risk assessments and the public debate. Food Chem. Toxicol. 2004, 42, 335-349.

11. Xiong, Y.; Wang, Y.; Yu, Y.; Li, Q.; Wang, H.; Chen, R.; He, N. Production and characterization of a novel bioflocculant from Bacillus licheniformis. Appl. Environ. Microb. 2010, 76, 2778-2782.

12. Salehizadeh, H.; Shojaosadati, S.A. Isolation and characterisation of a bioflocculant produced by Bacillus firmus. Biotechnol. Lett. 2002, 24, 35-40.

13. Kim, D.G.; La, H.J.; Ahn, C.Y.; Park, Y.H.; Oha, H.M. Harvest of Scenedesmus sp. with bioflocculant and reuse of culture medium for subsequent high-density cultures. Bioresour. Technol. 2011, 102, 3163-3168. 
14. Aljuboori, A.H.R.; Idris, A.; Abdullah, N.; Mohamad, R. Production and characterization of a bioflocculant produced by Aspergillus flavus. Bioresour. Technol. 2013, 127, 489-493.

15. He, J.; Zhen, Q.; Qiu, N.; Liu, Z.; Wang, B.; Shao, Z.; Yu, Z. Medium optimization for the production of a novel bioflocculant from Halomonas sp. V3a' using response surface methodology. Bioresour. Technol. 2009, 100, 5922-5927.

16. Piyo, N.; Cosa, S.; Mabinya, V.L.; Okoh, A.I. Assessment of bioflocculant production by Bacillus sp. Gilbert, a marine bacterium isolated from the bottom sediment of Algoa Bay. Mar. Drugs 2011, 9, 1232-1242.

17. Mabinya, V.L.; Cosa, S.; Nwodo, U.U.; Okoh, A.I. Studies on bioflocculant production by Arthrobacter sp. Raats, a freshwater bacteria isolated from Tyume River, South Africa. Int. J. Mol. Sci. 2012, 13, 1054-1065.

18. Daolun, L.F.; Shihong, H.X. Characterization of bioflocculant MBF3-3 produced by an isolated Bacillus sp. World J. Microbiol. Biotechnol. 2008, 24, 1627-1632.

19. Zhang, Z.; Lin, B.; Xia, S.; Wang, X.; Yang, A. Production and application of a novel bioflocculant by multiple-microorganism consortia using brewery wastewater as carbon source. J. Environ. Sci. 2007, 19, 667-673.

20. Park, Y.S.; Kang, S.W.; Lee, J.S.; Hong, S.I.; Kim, S.W. Xylanase production in solid state fermentation by Aspergillus niger mutant using statistical experimental designs. Appl. Microbiol. Biotechnol. 2002, 58, 761-766.

21. Mishra, A.; Kumar, S.; Kumar, S. Application of Box-Benhken experimental design for optimization of laccase production by Coriolus versicolor MTCC138 in solid-state fermentation. J. Sci. Ind. Res. 2008, 67, 1098-1107.

22. Liu, W.; Wang, K.; Li, B.; Yuan, H.; Yang, J. Production and characterization of an intracellular biofloculant by Chryseobacterium daeguense W6 cultured in low nutrition medium. Bioresour. Technol. 2010, 101, $1044-1048$.

23. Wu, J.Y.; Ye, H.F. Characterization and flocculating properties of an extracellular biopolymer produced from a Bacillus subtilis DYU1 isolate. Process Biochem. 2007, 42, 1114-1123.

24. Ahamed, A.; Vermette, P. Enhanced enzyme production from mixed cultures of Trichoderma reesei RUT-C30 and Aspergillus niger LMA grown as fed batch in a stirred tank bioreactor. Biochem. Eng. J. 2008, 42, 41-46.

25. Fujita, M.; Ike, M.; Tachibana, S.; Kitada, G.; Kim, S.M.; Inoue, Z. Characterization of a bioflocculant produced by Citrobacter sp. TKF04 from acetic and propionic acids. J. Biosci. Bioeng. 2000, 89, 40-46.

26. Deng, S.B.; Bai, R.B.; Hu, X.M.; Luo, Q. Characteristics of a bioflocculant produced by Bacillus mucilaginosus and its use in starch wastewater treatment. Appl. Microbiol. Biotechnol. 2003, 60, 588-593.

27. Saez, J.M.; Benimeli, C.S.; Amoroso, M.J. Lindane removal by pure and mixed cultures of immobilized actinobacteria. Chemosphere 2012, 89, 982-987.

28. Nwodo, U.U.; Green, E.; Mabinya, L.V.; Okaiyeto, K.; Rumbold, K.; Obi, L.C.; Okoh, A.I. Bioflocculant production by a consortium of Streptomyces and Cellulomonas species and media optimization via surface response model. Colloids Surf. B Biointerf. 2014, 116, 257-264. 
29. Yang, Z.H.; Huang, J.; Zeng, G.M.; Ruan, M.; Zhou, C.S.; Li, L.; Rong, Z.G. Optimization of flocculation conditions for kaolin suspension using the composite flocculant of MBFGA1 and PAC by response surface methodology. Bioresour. Technol. 2009, 100, 4233-4239.

30. Nwodo, U.U.; Okoh, A.I. Characterization and flocculation properties of biopolymeric flocculant (glycosaminoglycan) produced by Cellulomonas sp. Okoh. J. Appl. Microbiol. 2013, 114, 1325-1337.

31. Jeong, J.H.; Kim, J.N.; Weeb, Y.J.; Ryu, H.W. The statistically optimized production of poly(c-glutamic acid) by batch fermentation of a newly isolated Bacillus subtilis RKY3. Bioresour. Technol. 2010, 101, 4533-4539.

32. Rodrigues, L.; Teixeira, J.; Oliveira, R.; van der Mei, H.C. Response surface optimization of the medium components for the production of biosurfactants by probiotic bacteria. Process Biochem. 2006, 41, 1-10.

33. Wang, Q.; Hou, Y.; Xu, Z.; Miao, J.; Li, G. Optimization of cold-active protease production by the psychrophilic bacterium Colwellia sp. NJ341 with response surface methodology. Bioresour. Technol. 2008, 99, 1926-1931.

34. Schmitt, J.; Flemming, H. FTIR-spectroscopy in microbial and material analysis. Int. Biodeterior. Biodegrad. 1998, 41, 1-11.

35. Coates, J. Interpretation of infrared spectra, a practical approach. Encycl. Anal. Chem. 2000, doi:10.1002/9780470027318.a5606.

Sample Availability: The samples we used for the studies are available; both the bioflocculants and the actinobacterial species.

(C) 2014 by the authors; licensee MDPI, Basel, Switzerland. This article is an open access article distributed under the terms and conditions of the Creative Commons Attribution license (http://creativecommons.org/Licenses/by/3.0/). 